\title{
МУЗИЧНО-ВИКОНАВСЬКА КОМПЕТЕНТНІСТЬ ВЧИТЕЛЯ МУЗИЧНОГО МИСТЕЦТВА
}

\section{Ван Інчжи}

здобувач третього (освітньо-наукового) рівня вищої освіти кафедри освітології та інноваційної педагогіки, Харківський національний педагогічний університет імені Г. С. Сковороди, м. Харків, Україна

У статті, на основі аналізу музично-виконавської діяльності вчителя музики, обтрунтовано формування музично-виконавської компетентності. Визначено ї̈ структуру, яка складається з: музично-теоретичних, мисленнєво-операційних, комунікативно-організаційних, інтерпратацуійно-дослідницьких знань та умінь.

Ключові слова: музично-виконавська компетентність, вчитель музичного мистецтва.

In the article, based on the analysis of the musical performance activity of a music teacher, the formation of musical performance competence is substantiated. Its structure is determined, consisting of musical-theoretical, mental-operational, communicative-organizational, interpretive-research knowledge and skills.

Key words: musical performance competence, teacher of musical art

Ядром професійної компетентності вчителя музичного мистецтва $\epsilon$ його музично-виконавська компетентність. Поставивши завдання розкриття їі змісту, ми звернулися до аналізу специфіки професійної діяльності вчителя музики.

Різні аспекти підготовки музикантів представлено у дослідженнях з естетики мистецької освіти (П. Антохін, В. Бєхтєрєв, В. Гасилов, О. Олексюк, Ю. Рагс), музичної психології (Т. Адорно, І. Бех, Д. Кірнарська, М. Ярмаченко); соціології мистецтва (Ю. Давидов, І. Зязюн, А. Мудрик, Б. Смирнов, М. Шкіль). Історико-педагогічний аналіз інструментальної галузі подано у наукових студіях Н. Гуральник, М. Давидова, О. Зав’ялової, А. Козир, Г. Ніколаї та ін.

Специфіка професійної діяльності вчителя музики визначається необхідністю тісного взаємозв'язку елементів, що входять до поняття «вчитель» і поняття «музикант». При цьому володіння музичним інструментом $є$ найважливішим із умінь. Дослідники дійшли висновку, що основним видом музично-педагогічної діяльності вчителя музики 
$є$ музично-виконавська, «без якої вчитель музики не називався б учителем музики» (Г. Ципін).

Музично-виконавська діяльність вчителя музики - це опосередкована взаємодія виконавця (вчителя) та автора музичного твору, спрямована на відтворення, розкриття і донесення до слухача (студента) художнього образу, авторського задуму. Вона полягає в освоєнні тексту (музичної мови) твору, в тлумаченні ідеї, художнього образу і змісту твору, у відборі виразних засобів для найбільш точної передачі змісту композиторського задуму. Здатність до глибокого і правдивого тлумачення музичних творів тісно пов'язана зі світоглядом, загальною культурою, різнобічними знаннями, музичними здібностями, емоційно-вольовими якостями і складом мислення особистості [1, с. 54]. Цими факторами визначається успішність музично-виконавської діяльності.

Формування музично-виконавської компетентності учителів музичного мистецтва відбувається під час вивчення дисциплін професійного циклу («Основний музичний інструмент», «Диригування», «Постановка голосу»). Результатом їх опанування є складання заліків та іспитів у формі концертного виступу. Також майбутні фахівці беруть участь у інструментальних та вокальних концертах, фестивалях і конкурсах різних рівнів, де необхідно продемонструвати своє володіння інструментом, голосом, можливість керівництва хором. Така діяльність передбачає сформовану музично-виконавську компетентність.

Вивчення навчальної дисципліни «Основний музичний інструмент» має усталені традиції, що виявляються в академічній підготовці до виконавської діяльності. Водночас, вимоги до якісної підготовки сучасних фахівців, вимагають спеціального засвоєння музично-історичного й музично-теоретичного матеріалу. Учителі музичного мистецтва мають уміти його дидактично переробляти з урахуванням конкретних педагогічних завдань і досвіду студентів, творчо підходити до використання відповідних знань, а також відбору музичних творів.

О. Щербініна вважає, що набуття історико-теоретичних знань методичного спрямування в інструментальному класі відбувається здебільшого стихійно. Має місце порушення взаємозв'язків, диспропорція між аналітичним та праксеологічним компонентами, що зумовлює недостатній рівень освіченості у музикантів-педагогів, зниження креативного потенціалу їх виконавської діяльності [6, с. 122]. Саме 
тому, не залежно від попередньої виконавської підготовки, формування музично-виконавської компетентності учителів музичного мистецтва набуває певних складностей.

Враховуючи це положення, вважаємо, що майбутні фахівці мають опанувати низкою знань та вмінь, що складають, на нашу думку, музично-виконавську компетентність учителів музичного мистецтва: музично-теоретичні, мисленнєво-операційні, комунікативно-організаційні, інтерпратаційно-дослідницькі.

Музично-теоретичні знання, якими повинен оволодіти вчитель музичного мистецтва у процесі інструментальної підготовки допомагають у роботі над музичним репертуаром, де студент має усвідомити, що історія інструментального мистецтва представлена творчістю видатних композиторів та їх творами. Ці твори, як представники певної епохи, несуть на собі печатку свого часу і місця створення (національної школи), особистості творця і конкретного художнього задуму. Тому кожний музичний твір важливо розглядати як певну художню цілісність, як представника музичного мистецтва конкретного стилю.

Мисленнєво-операційні уміння майбутніх викладачів спрямовані на формування та оперування художніми образами. Музичні образи мають, перш за все, емоційний зміст, який виявляється в образно-почуттєвій формі. Музичний образ часто характеризується дослідниками (С. Волков, А. Сохор) як «музична побудова», яка несе в собі певну емоційну інформацію і створює можливості для інтерпретаційної варіативності [5, с. 109]. 3 цим процесом пов'язана работа музичного мислення, яке «можна визначити як моделювання системи ставлень суб'єкта до реальної дійсності, яке реалізується у процесі інтонування» [2].

У музичній психології феномен художнього мислення розглядається як сукупність знань у дії, тобто він є своєрідною формою людського мислення взагалі. Складність його вивчення полягає в тому, що всі компоненти художнього мислення функціонують і взаємодіють одночасно [4, с. 368].

Оволодіння даними уміннями може бути дієвим і професійно спрямованим тільки у поєднанні зі словом, яке допомагає розкрити музичні символи, осмислити та донести зміст музичних образів. Отже, наступним у музично-виконавській діяльності учителів музичного мистецтва вважаємо комунікативно-організаційні уміння. Їх сутність 
полягає в обміні думками і почуттями між суб'єктами спілкування, здатності взаємодіяти один з одним, організовувати як власне навчання, так і діяльність інших.

Особливість комунікації засобами музичного мистецтва виявляється у першочерговості емоційного аспекту художньої інформації. В. Остроменський наголошує, що: «Неможливість адекватного перекладу емоційної складової музичного змісту на іншу мову безперечна. Але в деяких випадках визначена ії частка піддається відносному перекладу, що не порушує загального положення про неможливість перекладення» [3, с. 72].

Зазначимо, що інтерпретація музичних творів здійснюється в процесі їх виконання. Як зазначають дослідники Г. Падалка, С. Шип, О. Щолокова, існує вербальна їх інтерпретація. На думку вчених, майстерність слова є обов'язковим компонентом діяльності педагога. Лекторська виконавська діяльність передбачає підготовку усного виступу, його озвучення і сценічну реалізацію. Її особливість полягає в тому, що необхідний текст не просто читається, а виконується.

Інтерпратаційно-дослідницькі уміння, що безпосередньо пов’ язані 3 музично-теоретичними знаннями, передбачають самостійне поповнення своїх знань, умінь орієнтуватися у стрімкому потоці музичної інформації. Самостійна навчально-дослідна робота учителів музичного мистецтва виявляється у: здатності бачити проблему, сформулювати ціле, задачі, проаналізувати факти, зробити власні висновки і узагальнення; оволодінні навичками порівняння, зіставлення, оцінювання, класифікації явищ відповідно до усталених критеріїв, вмінні виділяти суттєві причинно-наслідкові зв'язки; можливості здійснювати міжпредметні зв'язки і виявляти зв'язки між іншими явищами, формулювати висновки.

Особливої актуальності набувають уміння надавати самостійну художньо-естетичну оцінку музичним творам, узагальнювати окремі факти, оригінальності та неординарності мислити для розкриття змісту музичного твору. Усе це потребує залучення різної мистецтвознавчої літератури (пошук, відбір, аналіз), у результаті чого активізується пошукова діяльність студентів.

Отже, спираючись на теоретичні положення, що розкривають особливості музично-виконавської діяльності вчителя музики, ми визначили музично-виконавську компетентність майбутнього вчителя му- 
зики як інтегративне утворення особистості, що має системну організацію, складну багаторівневу структуру і виступає як сукупність, взаємодія особистісного, когнітивно-діяльнісного і рефлексивного компонентів, ступінь сформованості яких дозволяє вчителеві музики ефективно здійснювати музично-виконавську діяльність.

\section{Список використаних джерел:}

1. Готсдинер А. ЛI. О воспитании музыкой и музыкальном слухе. Роль музыки в эстетическом воспитании детей и юношества. Днепропетровск : Музыка, 1980. c. 41-57.

2. Зайцева А. Закономірності формування художньо-комунікативної культури майбутнього вчителя музики. Наук. часопис НПУ імені М. П. Драгоманова. Теорія і методика мистецької освіти. Вип. 18 (23), 2015. c. $97-191$.

3. Остроменський В. Д. Восприятие музыки как педагогическая проблема. Київ : Музична Україна, 1975. 147 с.

4. Петрушин В. А. Музыкальная психология: учеб. пособ. Москва : Гуманитарный издательский центр ВЛАДОС, 1997. 384c.

5. Сохор А. Интерпретация. Москва : Музыкальная энциклопедия, Советский композитор, 1979, т. 2. С. 109-110.

6. Щербініна О. М. Методичне забезпечення фортепіанної підготовки студентів у контексті інформатизації сучасної музичної освіти. Науковий часопис НПУ ім. М. Драгоманова. Теорія і методика мистецької освіти. 2015. Вип. 18 (23). с. 119-123. 